IBIMA Publishing

Journal of e-Learning and Higher Education

https://ibimapublishing.com/articles/JELHE/2019/121518/

Vol. 2019 (2019), Article ID 121518, 14 pages, ISSN : 2169-0359

DOI: $10.5171 / 2019.121518$

Research Article

\title{
Does Blended Learning Enhance Student Engagement? Evidence from Higher Education
}

\author{
Jolly Sahni \\ Department of Management, College of Business Administration, \\ Prince Sultan University, Riyadh, Saudi Arabia \\ jsahni@psu.edu.sa
}

Received date: 3 August 2018; Accepted date: 12 December 2018; Published date: 16 January 2019

Academic Editor: Maurice Abi Raad

Copyright (C) 2019. Jolly Sahni. Distributed under Creative Commons CC-BY 4.0

\begin{abstract}
Technology advancements in the present era have tremendous impact on teaching and learning as well. The present research aims to answer the research question; whether use of technology would help and support autonomous learning and also enhance student engagement? To assess this, blended learning approach was applied in a business course. "Blended learning" refers to combining face-toface learning with online learning experience. The detailed findings of a study conducted to assess the impact of blended learning initiative on student's engagement and overall learning in a business course has been reported in the paper. In addition, it also draws student's perspective on blended learning approach. LMS (Learning Management System), the eLearning platform, was extensively used for flipped classroom and other activities which were applied in Organizational Behavior course throughout one semester (16 weeks). Multiple sources were used for data collected; focus-group interviews; student surveys and LMS records. For comparison purpose, the course learning outcome achievement data were collected from two sections of this course; first, the test group (Section A) and second the control group (Section B). The results clearly show an increase in students learning in the test group (where blended learning was applied), in terms of learning outcome achievement and overall engagement with online activities as well as in class activities. This was depicted in their online quiz results, time spent and quality of contribution on online forums, discussions and glossary. According to student's perspective (test group), they felt motivated as they had some control over time, place or pace for learning. The evidence is found for the positive outcomes of blended learning approach; leads to higher student achievement and improves student engagement. Based on the analysis, the study contributes with its fruitful findings to the literature of Blended learning. Strong implications can be drawn for both the Instructor and the Institutions who wish to implement blended learning approach. Consequently, meaningful reforms in the higher education can be future direction for the government.
\end{abstract}

Keywords: Blended learning, LMS (Learning management system), Flipped classroom, Autonomous learning, Student engagement

Cite this Article as: Jolly Sahni (2019)," Does Blended Learning Enhance Student Engagement? Evidence from Higher Education ", Journal of e-Learning and Higher Education, Vol. 2019 (2019), Article ID 121518, DOI: $10.5171 / 2019.121518$ 


\section{Introduction}

Advances in the digital technology have a tremendous impact on teaching pedagogies in higher education and students learning. The recent changes in education call for the integration of technology in higher education to be more effective and quick. Gone are the days of conventional teaching where classrooms had teachers in the center lecturing with slides on the projector, it is time to move ahead by embracing this change and integrating technology in teaching strategies which are more learner centered. This can be achieved by the use of multiple modalities for delivering the right content in the right form as single mode of delivery may not provide choices, engagement, learning and performance (Singh, 2003). Curriculum design has to encompass a variety of teaching and learning strategies to ensure successful learning at university (Bovill et al., 2016). One such innovative strategy in the context of higher education is blended learning.

The word 'Blended' means mixed or combined. It is defined by researchers as a mixed approach, integrating classroom teaching with online experience (Garrison and Kanuka, 2004; Picciano, 2009). It requires the physical presence of the instructor and students in the classroom and virtual presence on the chosen eLearning platform, where students have some control over time, place or pace (Friesen, 2012). The benefits of this approach include synergistic impact of the strengths of synchronous (face-to-face) and asynchronous (text-based Internet) learning activities (Garrison and Kanuka, 2004). Blended learning is facilitated by technology, also referred to as hybrid learning or B-Learning (Shu \& Gu, 2018), which means integrating technology with face to face teaching in classroom. It basically combines delivery of traditional class activities with computer-mediated and online instructions (Allen et al., 2007). Therefore, teachers play the role of facilitators and students can participate, learn and question even outside the classroom which is more and more engaging for both the teacher and the students.

The choice of teaching and learning approach directly influences the student's learning experience, engagement and overall achievement (Honey and Mumford, 1986; Biggs and Tang, 2007). Literature suggests that blended learning approach can be successfully implemented in higher education (Mitchell and Honore, 2007; Garrison and Vaughan, 2008 Harris et al., 2009; Okaz, 2015; Halverson et al., 2017; Lopez, 2018). However, in the field of business education, only a few studies have examined the role of blended learning. Moreover, there is a lack of research on students' interaction with blended learning environment.

Against this backdrop, the present study aims to examine the role of blended learning approach in supporting autonomous learning and enhancing student engagement in a business course. The study is guided by the research question: "Does blended learning approach support autonomous learning and enhance the student engagement in a business course in higher education?" To capture the impact of blended learning approach on students, data were collected through multiple sources which helped the researcher reach reliable and concrete conclusions.

In the context of Saudi Arabia, higher education is now given priority in developing the human resources in the form of productive citizens. Quality education matters more than ever, reflected in Saudi vision 2030: "An education that contributes to economic growth: we will close the gap between the outputs of higher education and the requirements of the job market...we shall help our students achieve results above international averages in global education indicators" (Saudi Vision 2030, P-39). It also aims to develop digital infrastructure by 2030 . Therefore, there is a strong need to integrate technology with the class room teaching that enables the students to 
develop the required attitude for appreciating the role of digital technology in building a constructive society. The students of today are the future leaders of Saudi Arabia.

The paper is arranged as follows: after the introduction the second section presents review of relevant literature, in the third section, research methodology is discussed, fourth, results and discussion from the study are presented and lastly, conclusion with future directions are discussed in section five.

\section{Literature Review}

Blended learning has received due attention as one of the effective approaches to teaching and learning and it has been increasingly researched in recent decade (Garrison \& Vaughan, 2008; Staker \& Horn, 2012; Moskal et al., 2013; Porter et al., 2014: Manwaring et al., 2017). Literature suggests that there is a lack of consensus among researchers on the definition of blended learning as it has different interpretations by scholars. However, a common meaning can be derived; it is a teaching and learning approach that integrates web-based teaching and face-toface classroom interactions. It is defined by researchers as integrating classroom teaching with online experience (Garrison and Kanuka, 2004; Collins \& Blake, 2007). Another definition focusing on the combined approach suggests "A pedagogical approach that combines the effectiveness and socialization opportunities of the classroom with the technologically enhanced active learning possibilities of the online environment" (Dziuban, et al., 2004). Moreover, Driscoll (2002) argues that intermixing of any instructional form to achieve educational goals would represent blended learning. Similarly, according to Graham (2006), blended learning can be merging any two mediums of instructions, merging the best features of traditional face to face instruction and online learning. In addition to the computer platform in the form of online eLearning medium, researchers have also explored the effectiveness of blending conventional classroom teaching with mobile technology as a tool to promote collaborative learning (Heflin et al., 2017). Thongmak, (2013) in his study, examined the use of online social networks as one form of teaching tools. He found that the platform called Edmogo is effective in enhancing online communication for both students and teachers in Thailand. Particularly, in higher education, blended learning has gained substance in academic literature in the last decade (Bonk et al., 2005; Browne, 2010; Porter et al., 2014).

Past studies have established that if blended learning is designed and implemented properly, it may empower students to control their pace of learning as well as learning environment (Becker and Dwyer, 1994). According to a study by Twigg (2003) redesigning a course with blended learning resulted in greater understanding of the concept as well as higher results leading to improvement in learning outcomes. Salamonson and Lantz (2005) argue that blended learning results in high student satisfaction. It has also been considered as an innovative approach involving modern conceptions of learning (Allen et al., 2007). An important point to highlight is blended learning conceptualizes learning as an ongoing process than a single time event; this motivates students to learn and be engaged even outside the classroom (Borba, 2014). Learners get the benefit by increased flexibility which allows them to access the Internet and work on the course material whenever and wherever they prefer (Owston et al., 2006, 2013). It helps students learn in their own pace, get immediate feedback as and when their answer goes wrong, have access to lessons and videos from anywhere, submit assignments digitally, helps them become independent learners and promote autonomous learning. In addition to these benefits, blended learning also accommodates the diverse needs and interest of students (Dias \& Diniz, 2014).

Blended learning is accompanied with plethora of benefits, however, there are few 
conditions associated with its success. First, learners and teachers must be equipped and trained to use information technology tools. Second important requirement is to have a devoted technical center which can support both the learner and the teacher in the implementation of blended learning. Also, the technological requirements such as, Internet connection, speed and bandwidth must be considered for blended learning courses (Stewart, 2002). Literature suggests that learners' readiness is equally important in terms of attitude, motivation and skills for implementing such an approach (BaldwinEvan, 2006; Mitchell and Honore 2007). In addition, a recent study by Shu \& Gu (2018) highlighted the significance of the nature and differences of group interactions in the learning components which play an important role in the success of blended learning.

Another important concern is the student's involvement and engagement with this form of teaching approach. Student engagement can be depicted in active commitment, involvement and being occupied with the subject. Research suggests that it is a psychological process of enhancing attention and interest in the work of learning (Newmann et al, 1992, Marks, 2000). Students' engagement is multifaceted; it may be assessed at three levels, behavioral, affective and cognitive. Studies have also focused on accessing students' emotional reaction to academic work (Bodovski \& Farkas, 2007). Affective engagement is primarily measured by students' appreciation and liking of the subject whereas cognitive engagement refers to the mental effort invested in academic work (Fredricks et al, 2004). Research suggests that strategy of blended learning enhances student engagement through online activities and improves effectiveness (Whitelock \& Jefts, 2003).

\section{Methodology}

This section discusses the research approach, data collection sources, sample and data analysis. Research is guided by the question; "Does blended learning approach support autonomous learning and enhance student engagement?" Blended learning approach was adopted in a business course which is taken in the second year of graduation program. The course Organizational behavior was taught in two different sections, for one section the course was redesigned to incorporate blended learning approach and the second section followed only the traditional form of course delivery. The first section incorporates the blended learning approach where lectures in classroom were complemented with many activities on the eLearning platform (activities are shown in Table 3). This section will be referred to as test group.

\section{Data Collection}

Data were collected mainly from three sources; focus -group interviews; student surveys and LMS records. The triangulation research approach ensures reliability and validity. In addition, course learning outcome achievement data were collected from both sections of this course.

The study had two phases of data collection; the first was qualitative and involved recording students' focus group interview. Focus group interviews were conducted with a random sample of students from test group with their consent in the eleventh week of semester. All the interviews were recorded, transcribed and coded afterwards to find similar themes. The interviews lasted from 40 to 70 minutes. In the next phase, survey questionnaire was distributed to the test group (Section A) of thirty students taking OB course. The instrument used in the present study has been adapted from studies of Manwaring et al., (2017) for assessing learner's characteristics and proficiency with technology and study by Lin et al. (2018) for the set of items which are indicators of student engagement. The survey questionnaire was divided in three sections: first section gathered background information of the respondent, second section assessed the student engagement (emotional and cognitive) and the third section aimed to assess the Learner's 
characteristics variables such as Self Efficacy, Subject Interest and Tech-efficacy of students.

\section{Data Analysis}

Data were analyzed with the help of statistical package for social sciences, SPSS 22. Descriptive statistics were calculated for all the variables used in the selfadministered survey. The reliability of scale for internal consistency, Cronbach's alpha coefficient is calculated to be 0.810 . Reliabilities for subscales fall between 0.69 and 0.81 , which is considered satisfactory (Nunnally, 1978). The descriptive statistics such as mean and standard deviation for all variables in the study were attained.

Further, interviews with focus group were recorded and transcribed. With a continuous comparative approach and content analysis, patterns, themes and categories were identified and grouped together. To triangulate, these themes were then compared with the result of survey open ended questions.

\section{Findings and Discussion}

This section presents the results of blended learning approach in the organizational behavior course undertaken by students of second year of business under graduation program. Past studies have shown that eLearning platforms often give similar performance as of conventional face-to face method (Cook et. al 2008). The purpose of the present study was to assess whether a combination of eLearning and traditional face-to face method increases students' engagement and ultimately improves the learning outcome. Therefore, the study examined the impact of blended learning on student engagement (emotional and cognitive), learners' characteristics variable (self efficacy, subject interest and tech-efficacy), students' time and quality of discussion on LMS and finally the perceptions of the students about the blended approach in their learning. For section A (test group), the following changes were made to the tradition course in order to incorporate blended learning:
- The course page on LMS was redesigned to make it more attractive and user friendly

- Each session of the class was linked to video/picture which was posted on LMS one day prior to regular class

- Online Forum was activated by the instructor, where students discuss the topic given online. Students were allowed to post text, video or audio.

- To engage students more, case-lets were uploaded on LMS to be read by all students for next day class activity

- To recap and review the previous chapter, students were given online quizzes

- All assignment guidelines were uploaded by the instructor on LMS and submitted by students on LMS

- All students were required to submit the course Project online through Turnitin assignment page.

- To have more interaction through online medium, a special midcourse feedback session was organized on LMS, where students can anonymously rate and give their opinion on course delivery.

\section{Profile of Participants}

The test group (Section A) consists of thirty students with diverse skills, studying the undergraduate degree in business education at a private women university in Saudi Arabia. All students of test group were informed about the project and were asked for consent for their data to be used in a study. Table 1 depicts the brief profile of participating students. As it is a case of women university, all participants are female. Approximately, 77 percent of respondents were below the age of 20 years. Only three students were married which represents 10 percent of the whole sample. Almost 76 percent of respondents were from the local city of Riyadh (Saudi 
Arabia) while 23 percent were from

and Sudan. neighboring countries like Yemen, Egypt

Table 1: Profile of participants

\begin{tabular}{|l|l|l|}
\hline \multicolumn{1}{|c|}{ Category } & \multicolumn{1}{c|}{ Number } & Percentage \\
\hline \multicolumn{3}{|c|}{ GENDER } \\
\hline Female & \multicolumn{1}{|c|}{ AGE } & 100 \\
\hline Male & 0 & 0 \\
\hline \multicolumn{3}{|c|}{} \\
\hline Under 16 Years & 0 & 0 \\
\hline 17-18Years & 4 & 13.33 \\
\hline 19-20 Years & 19 & 63.33 \\
\hline 21-21Years & 6 & 20 \\
\hline 22 or Older & 2 & 6.66 \\
\hline \multicolumn{3}{|c|}{ MARITAL STATUS } \\
\hline Un Married & 27 & 90 \\
\hline Married & 3 & 10 \\
\hline \multicolumn{3}{|c|}{ NATIONALITY } \\
\hline Saudi & 23 & 76.66 \\
\hline Non-Saudi & 7 & 23.33 \\
\hline
\end{tabular}

\section{Descriptive Statistics}

The evaluation of findings draws on the data from the practical experience of students on the course and real time data from LMS logs. Table 2 depicts the description of variables used in the survey on student engagement and learners' characteristics. The survey scores suggest that the students were highly engaged while they were performing activities online. However, the emotional engagement was found to be $78.6 \%$ and the cognitive engagement was surprisingly higher than emotional engagement, it was found to be $88 \%$ among the sample of students. The least score was received by item under emotional engagement, "Did you wish you had been doing something else?" whereas the item from cognitive engagement called "How well were you concentrating?" scored the highest among all, which clearly depicts the higher level of cognitive engagement among students. Considering the learners' characteristics, the results depict that self efficacy scored $80.3 \%$, subject interest received overall $83.3 \%$ and tech-efficacy also received a good score of $88.4 \%$, which means on all variables of learners' characteristics, the scores can be considered high and that the group of students were ready for the new approach of blended learning, especially the teach-efficacy. Data from the survey clearly depict that the applied approach was successful in enhancing engagement; both affective and cognitive. 
Table 2 Description of variables

\begin{tabular}{|c|c|c|c|}
\hline Factor & Indicator & Average & Std. Dev \\
\hline Emotional Engagement & Did you enjoy the LMS activities? & 3.72 & .594 \\
\hline Cognitive Engagement & $\begin{array}{l}\text { How well were you } \\
\text { concentrating? }\end{array}$ & 4.4 & .744 \\
\hline Emotional Engagement & Did you feel good about yourself? & 3.96 & .613 \\
\hline Emotional Engagement & $\begin{array}{l}\text { Do you like to participate in these } \\
\text { activities on LMS }\end{array}$ & 3.88 & .824 \\
\hline Cognitive Engagement & $\begin{array}{l}\text { Were you learning anything or } \\
\text { getting better at something? }\end{array}$ & 3.96 & .821 \\
\hline Emotional Engagement & Did you experience frustration? & 2.76 & .986 \\
\hline Cognitive Engagement & $\begin{array}{l}\text { Did you set a goal for yourself } \\
\text { prior to the LMS activity? }\end{array}$ & 2.72 & .921 \\
\hline Emotional Engagement & $\begin{array}{l}\text { Did you feel socially connected to } \\
\text { anybody during this learning } \\
\text { activity? }\end{array}$ & 3.48 & .691 \\
\hline Cognitive Engagement & $\begin{array}{l}\text { How challenging were the } \\
\text { activities on LMS? }\end{array}$ & 2.68 & 1.009 \\
\hline Cognitive Engagement & Was it important to you? & 3.84 & .799 \\
\hline Emotional Engagement & $\begin{array}{l}\text { Did you wish you had been doing } \\
\text { something else? }\end{array}$ & 2.52 & 1.042 \\
\hline Emotional Engagement & Were these activities interesting? & 3.88 & .583 \\
\hline Cognitive Engagement & $\begin{array}{l}\text { How important was it to your } \\
\text { future goals? }\end{array}$ & 3.36 & .788 \\
\hline Cognitive Engagement & $\begin{array}{l}\text { Were you able to relate it to what } \\
\text { you already know? }\end{array}$ & 4.24 & .761 \\
\hline Emotional Engagement & $\begin{array}{l}\text { I think we can learn more by } \\
\text { being active on LMS and } \\
\text { participating in the activities }\end{array}$ & 3.71 & .961 \\
\hline Emotional Engagement & $\begin{array}{l}\text { I would like to have similar } \\
\text { activities in the next term also }\end{array}$ & 3.67 & .824 \\
\hline \multicolumn{4}{|c|}{ Learners Characteristic Variables } \\
\hline Self-efficacy & $\begin{array}{l}\text { I believe I will receive an } \\
\text { excellent grade in this class. }\end{array}$ & 4.04 & .921 \\
\hline Self-efficacy & $\begin{array}{l}\text { I am confident I can understand } \\
\text { the most complex material in this } \\
\text { course. }\end{array}$ & 4.63 & .680 \\
\hline Self-efficacy & $\begin{array}{l}\text { I am confident I can do an } \\
\text { excellent job on the assignments } \\
\text { and tests in this course. }\end{array}$ & 4.33 & .716 \\
\hline Self-efficacy & $\begin{array}{l}\text { Considering the difficulty of this } \\
\text { course, the teacher, and my skills, } \\
\text { I think I can do well in this class. }\end{array}$ & 4.38 & .788 \\
\hline Subject interest & $\begin{array}{l}\text { I like the subject matter of this } \\
\text { course. }\end{array}$ & 4.17 & .734 \\
\hline Subject interest & $\begin{array}{l}\text { I am very interested in the } \\
\text { content area of this course. }\end{array}$ & 4.17 & .921 \\
\hline
\end{tabular}




\begin{tabular}{|l|l|c|c|} 
& $\begin{array}{l}\text { Understanding the subject matter } \\
\text { of this course is very important } \\
\text { to me. }\end{array}$ & 4.21 & .711 \\
\hline Tech self-efficacy & $\begin{array}{l}\text { I am capable of solving or getting } \\
\text { help to solve my computer- } \\
\text { related problems. }\end{array}$ & 4.46 & 16.6 \\
\hline Tech self-efficacy & $\begin{array}{l}\text { I am very comfortable doing class } \\
\text { work that is online. }\end{array}$ & 4.29 & 16.0 \\
\hline Tech self-efficacy & $\begin{array}{l}\text { I am capable of using the Internet } \\
\text { to find information I need. }\end{array}$ & 4.54 & 16.9 \\
\hline Tech self-efficacy & I am comfortable with LMS & 4.43 & 16.9 \\
\hline
\end{tabular}

\section{LMS Data and Findings}

The activities on LMS ranged from forum discussions, online quizzes, chat rooms, online assignment submission, glossary, flipped class sessions, videos etc. The activities actually provoked their attention and engagement as students could interact with each other online rather than only accessing handouts and power point slides. Table 3 depicts the range of activities on LMS. Students' frequency of use of Moodle, learning management system (LMS) was examined by page hits and individual activity hits per student in this course.

Table 3: Range of activities on LMS

\begin{tabular}{|c|}
\hline Activities on LMS \\
\hline Online Quiz \\
\hline $\begin{array}{c}\text { Online Forum Discussion } \\
\text { Flipped classroom }\end{array}$ \\
\hline Chat discussion \\
\hline Online Personality Test \\
\hline Checklist (before Major) \\
\hline Mid-Course Feedback \\
\hline Glossary \\
\hline Mentoring Session \\
\hline Web Pages \\
\hline Group Project (Turnitin assignments) \\
\hline
\end{tabular}

Further, LMS records, in particular, were useful in assessing each student's quality of engagement and time spent on each activity. These data were compared and analyzed for sixteen weeks. Table 4 shows the assessment components of the course, their timing in 16 weeks. There is seen a direct association between the timings of assessment especially online assessment activities and the pattern of usage on LMS. As per the assessment results and students' feedback, the two activities which were most effective in learning and reviewing the concept were flipped class session and online quizzes (eQuiz). 
Table 4: Assessment components (16 weeks)

\begin{tabular}{|c|l|l|}
\hline Assessment & Assessment Task & Week Due \\
\hline 1 & Quiz (In-class) & Week 2 \\
\hline 2 & $\begin{array}{l}\text { Major Exam (In- } \\
\text { class) }\end{array}$ & Week 6 \\
\hline 3 & LMS Assignments & Week 2 \& 8 \\
\hline 4 & Online Quiz (4) & $\begin{array}{l}\text { Week 3, 4, } \\
\mathbf{1 0}, \mathbf{1 2}\end{array}$ \\
\hline 5 & Flipped class session & Week 7 \\
\hline 6 & Glossary & Week 10 \\
\hline 7 & Online Project & Week 12 \\
\hline & Total Assessment & \\
\hline
\end{tabular}

In addition, LMS logs were accessed to check the details of student participation in activities which were posted online during the month of February, March and April. During the month of February students were informed about the blended learning and activities online, they were in a transition mode and therefore few activities were uploaded on LMS. It was found that the highest participation was noted in the first week of March, this is when flipped classroom was implemented in this course (week 7). Student participation has clearly increased when compared to the section which did not implement blended learning. This was depicted in their on-line quiz results, time spent and quality of contribution on online forums, discussions and glossary. The data from LMS clearly show that students engage more with creative activities, however, the importance of face-to-face instructions and lecture remains. As highlighted in focus group interviews, where students raised their concern about not replacing traditional classroom teaching with online teaching, rather, they prefer both to complement each other. Specifically, the results suggest that blended learning, in addition to having a great potential to increase students' engagement and learning, was preferred over traditional methods of teaching and learning. The log results extracted from LMS show that out of 30 students enrolled in Section A (test group), 28 were actively engaged in the array of activities posted on LMS. Moreover, the quality of contribution in discussion forum was also found to be of a good standard.

In addition to students' activities and hits on LMS, the academic learning achievement was assessed through the final grades in $\mathrm{OB}$ course. The results clearly show an increase in students' learning in terms of learning outcome achievement and final grades when compared to the section which did not implement blended learning. The achievement of the overall course learning outcomes for the control section was 67 percent (Section B) whereas when measured for the test section it was not very high, however, it scored more than the control group, 71 percent (Section A). Examining the final grades, it was found that all students passed the course and 35 percent students scored an 'A+' and 'A' grade. When compared with the control section, only 28 percent students scored $A+$ ' and 'A' grade and two students failed the course. The finding suggests that the students' engagement in the test group of course 'organizational behavior' has improved with the application of blended learning approach. The results imply that students were motivated; they enjoyed a higher level of flexibility and had a sense of belongingness throughout the course learning. 


\section{Students' Perspective}

Students were highly satisfied with the blended learning approach and activities on LMS as they mentioned in the focus group interview that the strength of this approach according to their perspective include the convenience of it, it is accessible anywhere, at any time with instant feedback. Some themes identified in the focus group interview representing the students' perception are as follows:

Diversity and flexibility - "what I like about this course is the multiple activities on LMS and they were not the same topic, we had to think about diverse areas in the field of OB"

On-line Support - "All the activities were related and supportive to what we took in the class, when we are involved in doing practical activities, practice I think this is going to stay with us longer it is a life long learning for us"

Active engagement and learning "This course gave us a chance to contribute and participate more and learn more, the activities were fair for all and the transparency of feedback was there". Another student believed, "The activities actually engage us more, they are fun, they increase the diversity in the course, its not just that we go to the classroom and we take a lecture, its actually much more than that. I would like other courses to be like this one, with interesting and interactive activities on LMS, very informative and engaging course activities."

The above comments suggest that students perceived high value in this course delivery method. In addition, the researcher realized that the current generation is techy-savvy and likes to use advanced technology, therefore, if we channelize their energy in a right direction through the use of blended learning (using advanced technology), they can really produce great results.
Based on the results from the survey, focus group interview and LMS records, it is established that blended learning approach was successful in engaging students inside and outside the classrooms. The findings of this study are consistent with previous research which proved the strong relationship of blended learning with increased learner engagement and participation (Graham, 2007; Alebaikan \& Troudi, 2010; Napier et al., 2011; Vaughan 2014; Manwaring et al., 2017).

\section{Challenges in Implementing B-Learning}

Like any other innovative approach, the implementation of blended learning in higher education would face some challenges. The concerns can be categorized into three levels; first at Instructor level, second student level and third the technical support. The instructor must adopt the new tools with a new mindset and positive attitude as more time and commitment is required from the Instructors in preparing everything in advance and giving continuous feedback on eLearning platform. For students, they need to be motivated to adapt new technology and feel comfortable as well as have good time management skills. Another crucial aspect is the technical support in the classrooms; the variation in the speed of Internet connection in the classroom may hamper the effectiveness of the whole program. Therefore, a dedicated support from the technical center must be available in order to implement this effectively.

\section{Conclusion}

Given the importance of technology and technology driven classrooms in this age of dynamic development, there is a great need for understanding and promoting blended learning approach in higher education. In conclusion, this research study has helped us understand the impact of blended learning approach and clearly suggested the effectiveness of integrating technology in the classroom to promote autonomous 
learning and thereby enhancing student engagement. There are various benefits of blended learning approach; it is innovative in approach, results in active learning, more personalized learning, student centric and more engaging for students. This study showed how a balanced approach to blended learning can lead to higher student achievement and improve the student engagement.

Blended learning is more than just enhancing lectures, it represents transformation in how we approach teaching and learning. The potential of blended leaning in higher education is promisingly tremendous, a further research into the relevant practices and their impact is essential. Follow up with blended learning is equally important to assess the effectiveness in terms of achieving learning outcomes, student satisfaction and overall learning experience. We have the opportunity to create some massive technology enabled changes in what it means to be involved in obtaining an education and transforming the whole learning experience.

Based on the analysis, the study contributes with its fruitful findings in the literature of blended learning. Strong implications can be drawn for both the Instructor and the Institutes which wish to implement blended learning approach. Consequently, meaningful reforms in education can be the future direction for the governments.

\section{References}

1. Allen, I.E., Seaman, J. and Garrett, R., 2007. Blending in: The extent and promise of blended education in the United States. Sloan Consortium. PO Box 1238, Newburyport, MA 01950.

2. Baldwin-Evans, K., 2006. Key steps to implementing a successful blended learning strategy. Industrial and commercial training, 38(3), pp.156-163.
3. Becker, D.A.A. and Dwyer, M.M., 1994. Using hypermedia to provide learner control. Journal of educational multimedia and hypermedia, 3(2), pp.155-72.

4. Biggs, J. and Tang, C., 2007. Teaching for Quality Learning at University (3rd edn) Buckingham: SRHE and Open University Press.

5. Bodovski, K. and Farkas, G., 2007. Mathematics growth in early elementary school: The roles of beginning knowledge, student engagement, and instruction. The Elementary School Journal, 108(2), pp.115130.

6. Bonk, C.J., Kim, K.J. and Zeng, T., 2005, June. Future directions of blended learning in higher education and workplace learning settings. In EdMedia: World Conference on Educational Media and Technology (pp. 3644-3649). Association for the Advancement of Computing in Education (AACE).

7. Borba, M.C., Askar, P., Engelbrecht, J., Gadanidis, G., Llinares, S. and Aguilar, M.S., 2016. Blended learning, e-learning and mobile learning in mathematics education. ZDM, 48(5), pp.589-610.

8. Bovill, C., Cook-Sather, A., Felten, P., Millard, L. and Moore-Cherry, N., 2016. Addressing potential challenges in cocreating learning and teaching: overcoming resistance, navigating institutional norms and ensuring inclusivity in student-staff partnerships. Higher Education, 71(2), pp.195-208.

9. Browne, T., Hewitt, R., Jenkins, M. and Walker, R., 2008. 2008 Survey of Technology Enhanced Learning for higher education in the UK. UCISA. 
10. Collins, K. and Blake, R.M., 2007. Blended learning. Embracing individualism, Chief Learning Officer, 6(2), pp.32-37.

11. Cook, D.A., Levinson, A.J., Garside, S., Dupras, D.M., Erwin, P.J. and Montori, V.M., 2008. Internet-based learning in the health professions: a meta-analysis. Jama, 300(10), pp.1181-1196.

12. Dias, S.B. and Diniz, J.A., 2014. Towards an enhanced learning management system for blended learning in higher education incorporating distinct learners' profiles. Journal of Educational Technology \& Society, 17(1).

13. Manathunga, C. and Donnelly, R., 2009. Opening online academic development programmes to international perspectives and dialogue. In Applied e-learning and eteaching in higher education (pp. 85-109). IGI Global.

14. Driscoll, M., 2002. Blended learning: Let's get beyond the hype. E-learning, 1(4), pp.14.

15. Dziuban, C.D., Hartman, J.L. and Moskal, P.D., 2004. Blended learning EDUCAUSE Centre for Applied Research: Research Bulletin.

16. Graham, C.R., 2006. Blended learning systems. The handbook of blended learning, pp.3-21.

17. Garrison, D.R. and Kanuka, H., 2004. Blended learning: Uncovering its transformative potential in higher education. The internet and higher education, 7(2), pp.95-105.

18. Garrison, D.R. and Vaughan, N.D., 2008. Blended learning in higher education:
Framework, principles, and guidelines. John Wiley \& Sons.

19. Fredricks, J.A., Blumenfeld, P.C. and Paris, A.H., 2004. School engagement: Potential of the concept, state of the evidence. Review of educational research, 74(1), pp.59-109.

20. Friesen, N., 2012. Report: Defining blended learning. Learning Space.

21. Halverson, L.R., Spring, K.J., Huyett, S., Henrie, C.R. and Graham, C.R., 2017. Blended learning research in higher education and K-12 settings. In Learning, Design, and Technology (pp. 1-30). Springer, Cham.

22. Harris, P., Connolly, J. and Feeney, L., 2009. Blended learning: Overview and recommendations for successful implementation. Industrial and Commercial Training, 41(3), pp.155-163.

23. Heflin, H., Shewmaker, J. and Nguyen, J., 2017. Impact of mobile technology on student attitudes, engagement, and learning. Computers \& Education, 107, pp.91-99.

24. Honey, P. and Mumford, A., 1986. The Manual of Learning Styles, Honey and Mumford, Maidenhead.

25. Lin, F.L., Wang, T.Y. and Yang, K.L., 2018. Description and evaluation of a large-scale project to facilitate student engagement in learning mathematics. Studies in Educational Evaluation.

26. Littlejohn, A.H. \& Pegler, C., 2007. Planning for blended learning, Routledge, London ISBN 978-0-415-40361-0 
27. Lopez, D. R. S., Ayuela, M. A. D., Gonzalez Burgos, E., Serrano-Gil, A., \& Lalatsa, K., 2018. Technology enhanced learning in Higher Education: how to enhance student engagement through blended learning. European Journal of Education.

28. Manwaring, K. C., Larsen, R., Graham, C. R., Henrie, C. R., \& Halverson, L. R., 2017. Investigating student engagement in blended learning settings using experience sampling and structural equation modeling. The Internet and Higher Education, 35, 21-33.

29. Mitchell, A. and Honore, S., 2007. "Criteria for successful blended learning", Industrial and Commercial Training, Vol. 39 No. 3, pp. 143-9.

30. Moskal, P., Dziuban, C., \& Hartman, J., 2013. Blended learning: A dangerous idea?. The Internet and Higher Education, 18, 15-23.

31. Newmann, F. M., Wehlage, G. G., \& Lamborn, S. D., 1992. The significance and sources of student engagement. In Student engagement and achievement in American Secondary Schools, (pp. 11-39). New York, New York: Teachers College Press

32. Napier, N. P., Dekhane, S., \& Smith, S., 2011. Transitioning to blended learning: Understanding student and faculty perceptions. Journal of Asynchronous Learning Networks, 15(1), 20-32.

33. Okaz, A. A., 2015. Integrating blended learning in higher education. ProcediaSocial and Behavioral Sciences, 186, 600603.

34. Owston, R., York, D., \& Murtha, S., 2013. Student perceptions and achievement in a university blended learning strategic initiative. The Internet and Higher Education, 18, 38-46.
35. Owston, R.D., Garrison, D.R. and Cook, K., 2006. "Blended learning at Canadian universities: issues and

36. practices", in Bonk, C.J. and Graham, C.R. (Eds), The Handbook of Blended Learning: Global Perspectives, Local Designs, Pfeiffer, San Francisco, CA, pp. 502-14.

37. Picciano, A. G., 2009. Blending with purpose: The multimodal model. Journal of asynchronous learning networks, 13(1), 718.

38. Porter, W. W., Graham, C. R., Spring, K. A., \& Welch, K. R., 2014. Blended learning in higher education:

39. Institutional adoption and implementation. Computers \& Education, 75, 185-195.

40. Salamonson, Y., \& Lantz, J., 2005. Factors influencing nursing students' preference for a hybrid format delivery in a pathophysiology course. Nurse Education Today, 25(1), 9-16

41. Singh, H., 2003. Building effective blended learning programs. Educational Technology-Saddle Brook Then Englewood Cliffs NJ-, 43(6), 51-54.

42. Shu, H., \& Gu, X., 2018. Determining the differences between online and face-to-face student-group interactions in a blended learning course. The Internet and Higher Education.

43. So, H. J., \& Brush, T. A., 2008. Student perceptions of collaborative learning, social presence and satisfaction in a blended learning environment: Relationships and critical factors. Computers \& education, 51(1), 318-336.

44. Staker, H., \& Horn, M. B., 2012. Classifying $\mathrm{K}-12$ blended learning. Innosight Institute. 
45. Stewart, J. M., 2002. A blended e-learning approach to intercultural training. Industrial and Commercial Training, 34(7), 269-271.

46. Thomson and NETg."The Next Generation of Corporate Learning: Achieving the Right Blend, 2003.

47. Thongmak, M. , 2013. Social network system in classroom: Antecedents of edmodo (C) adoption. Journal of e-Learning and Higher Education, 2013(1), 1-15.

48. Twigg, C. A., 2003. Models for online learning. Educause review, 38, 28-38.
49. Vaughan, N., 2007. Perspectives on blended learning in higher education. International Journal on ELearning, 6(1), 81.

50. Vaughan, N., 2014. Student engagement and blended learning: Making the assessment connection. Education Sciences, $4(4), 247-264$.

51. Whitelock, D. \& Jefts, A., 2003. Editorial: Journal of Education Media Special issue on blended learning, Journal of Educational Media, 28(2-3), pp.99-100. 